\title{
ORIENTASI NILAI BUDAYA PETANI RUMPUT LAUT DALAM PEMBANGUNAN DI DESA PED KECAMATAN NUSA PENIDA
}

\author{
Ni Made Suwendri \\ Universitas warmadewa \\ suwendri63@gmail.com
}

\begin{abstract}
ABSTRAK
Orientasi nilai budaya manusia merupakan faktor penting dalam mencapai suatu tujuan. Hal ini dapat dilihat dari pandangannya terhadap kehidupan. Penelitian ini bertujuan untuk mendapatkan pemahaman mendalam tentang orientasi nilai budaya petani rumput laut dalam pembangunan di Desa Ped, Kecamatan Nusa Penida. Penelitian ini menggunakan pendekatan kualitatif yang didukung oleh data kuantitatif. Teknik pengumpulan data dilakukan melalui, observasi, wawancara mendalam, dan studi perpustakaan. Data dianalisis dengan metode kualitatif deskriptif. Berdasarkan data empiris menunjukkan bahwa orientasi nilai budaya yang digunakan oleh petani rumput laut di Desa Ped Kecamatan Nusa Penida di dalam memecahkan masalah-masalah kehidupan meliputi pandangan mereka terhadap hidup, pandangan terhadap karya, pandangan terhadap waktu, pandangan terhadap hubungan antar sesama manusia, dan pandangan manusia dalam hubungan dengan alam. Semua prinsip itu ditujukan untuk mencapai kemajuan. Orientasi tersebut menunjukkan pentingnya dinamika untuk keberhasilan pembangunan di Kecamatan Nusa Penida.
\end{abstract}

Kata kunci: orientasi nilai budaya, dinamika, petani rumput laut, pembangunan

\begin{abstract}
[Title: Cultural Value Orientation of the Seaweed Planters in Developing Ped Village, Nusa Penida District] Human's cultural value orientation becomes important factor in achieving the purpose. It can be seen from its view ofliving. This research is purposed to get the deep understanding of cultural value orientation seaweed plantersin building of Ped Village, Nusa Penida District. This research used qualitative approach which is supported byquantitative data. The technique of collecting data is done through observation' concern interview, and library research. The data is analyzed throughqualitative descriptive way. According to the empiric data, it shows that the cultural value orientation whichis used by seaweed planters in Ped village, Nusa Penida district in solving theliving problems including of their views to the principal of life, principal of work, principalof time, principal of human, and principal of human's relation with nature. Mostof the principal goes to the improvement. The orientation shows theimportant dynamic for the successful of building in Nusa Penida District.
\end{abstract}

Keywords: cultural value orientation, dynamic, seaweed planter, development

\section{PENDAHULUAN}

Pembangunan merupakan strategi yang harus dilakukan oleh suatu bangsa untuk memajukan taraf kehidupan warga masyarakatnya. Sebagaimana halnya pemerintah Indonesia dalam rangka mencapai tujuan nasional, telah menempuh kebijakan pembangunan yang dilaksanakan secara bertahap di segala sektor ke- 
hidupan.

Keberhasilan Pembangunan sangat ditentukan oleh kualitas sumber daya manusia dalam hal ini adalah menyangkut sikap mental/mentalitas yang dimiliki manusianya. Mentalitas merupakan suatu kapasitas rokhaniah yang terdapat pada seseorang yang menentukan perilaku berbuat atau bertindak dalam hidupnya (Mattulada, 1985: 48). Apa yang dinyatakan dalam perilaku itu membentuk sikap seseorang terhadap sesuatu yang lain. Sikap mental inilah yang sering disebut sebagai sistem nilai budaya (cultural value system).

Kluckhohn mengungkapkan bahwa sistem nilai budaya dalam suatu kebudayaan sesungguhnya menyangkut masalah-masalah dasar dalam hidup yang menentukan orientasi nilai budaya manusia. Orientasi nilai budaya dalam mencapai tujuan pembangunan nasional adalah salah satu faktor yang ikut membentuk potensi mentalitas manusia (Koentjaraningrat, 1987: 31).

Koentjaraningrat (1987) secara jelas mengindentifikasikan Pola-pola orientasi nilai budaya masyarakat Indonesia yang cukup berpengaruh terhadap keberhasilan pembangunan. Menurutnya, terdapat orientasi nilai budaya yang relevan akan mendukung kepentingan pembangunan dan sebaliknya orientasi nilai budaya yang kurang relevan akan menghambat pembangunan. Dalam pelaksanaan pembangunan yang sedang berlangsung tidak harus menunggu supaya ada kecocokan orientasi nilai budaya yang dianut oleh manusia dan masyarakat pendukung pembangunan, tetapi orientasi nilai budaya manusia pembangunan itu penting dipahami dan dikaji melalui penelitian untuk dapat disumbangkan bagi kelancaran pembangunan.

Di samping alasan tersebut di atas, faktor lain yang menjadi masalah dalam penelitian ini adalah sangat jarang ditemukan di kalangan pemuda atau remaja yang menggeluti pekerjaan sebagai petani rumput laut, padahal sektor ini cukup menjanjikan. Hal inilah yang menarik untuk diteliti lebih lanjut. Kecendrungankecendrungan yang muncul mengarah kepada terjadinya pergeseran-pergeseran orientasi nilai budaya.

Berdasarkan latar belakang tersebut di atas, akan dikaji beberapa permasalahan sebagai berikut: (1) Bagaimanakah orientasi nilai budaya petani rumput laut dalam pembangunan di Desa Ped Kecamatan Nusa Penida? (2) Seberapa jauh terjadi pergeseran atau dinamika orientasi nilai budaya di kalangan petani rumput laut di Desa Ped Kecamatan Nusa Penida?

Tujuan pokok yang hendak dicapai dalam penelitian ini adalah : (1) Pemahaman terhadap orientasi nilai budaya petani rumput laut dalam pembangunan. (2) Pemahaman terhadap terjadinya pergeseran-pergeseran atau dinamika orientasi nilai budaya di kalangan petani rumput laut.

Temuan yang dihasilkan dalam penelitian ini diharapkan dapat memberikan manfaat setidaknya memberikan sumbangan pola pikir/sikap mental yang perlu dikembangkan untuk kepentingan pembangunan bangsa dan sebaliknya mengadakan perubahan-perubahan terhadap mentalitas yang menghambat pembangunan.

Beberapa studi yang relevan dengan kajian ini antara lain: Koentjaraningrat dalam bukunya Kebudayaan Mentalitas dan Pembangunan (1987) mengungkapkan aneka warna orientasi nilai budaya masyarakat Indonesia dalam Pembangunan. Studi yang dilakukan tersebut menggunakan kerangka nilai budaya dari Klukhom. Koentjaraningrat mengetengahkan gambaran tentang orientasi nilai budaya petani khususnya petani Jawa. Gambaran orientasi nilai budaya 
Vol. 2, No. 1, Januari 2018, 36

Available Online at https://ejournal.warmadewa.ac.id/index.php/kulturistik

DOI: dx.doi.org/10.22225/kulturistik.2.1.447

petani tersebut adalah: (1) dalam hakekat masalah hubungan manusia dengan kerja, petani itu bekerja untuk hidup, terkadang bila memungkinkan untuk mencapai kedudukan; (2) Dalam hakikat masalah hubungan manusia dengan waktu, petani itu berorientasi ke masa sekarang dan terkadang ke masa lampau; (3) Dalam hakikat hubungan manusia dengan alamm petani mengutamakan orientasi selaras dengan alam; dan 4) Dalam hakikat masalah hubungan manusia dengan manusia, petani lebih berorientasi terhadap sesamanya.

Pentingnya aspek mental dalam pembangunan masyarakat, menurut Inkeles terdapat sebelas karakteristik mentalitas manusia modern sebagai berikut: (1) memiliki sikap pribadi yang terbuka, (2) memiliki dan mengembangkan sikap untuk selalu siap berubah, (3) menghargai perbedaan pendapat dalam banyak isu, (4) menghargai waktu secara tepat, (5) memperkaya diri dengan informasi, (6) memiliki kemampuan untuk merencanakan (managerial skill) (7) menghargai keberadaan orang lain sebagaimana adanya, (8) memiliki dan mengembangkan sikap percaya pada diri sendiri, (9) menilai ketrampilan teknis sebagai hal yang penting, (10) menghargai pentingnya pendidikan sebagai wahana pembangunan Iptek, dan (11) menghargai prinsip-prinsip demokrasi, (Inkeles, 1994).

McClelland dalam artikelnya, "Dorongan Hati Menuju Modernisasi (1994)," mengetengahkan tentang pendekatan psikologis dalam modernisasi. Dinyatakan bahwa virus mental yang diberi nama $n$-ach (need of achievement) kebutuhan berprestasi), merupakan faktor penyebab terjadinya perubahan dalam pemikiran manusia yang menghasilkan pertumbuhan ekonomi. Sumber-sumber motivasi prestasi yang penting dalam masyarakat negara adalah nilai-nilai, kepercayaan, dan idiologi (McClelland, n.d., 1994).

Dengan berkembangnya $n$-ach, seseorang akan mampu mengaktualisasikan berbagai potensi pribadinya secara memadai, sehingga ia akan mampu survive dalam berbagai segi kehidupan. Soedjatmoko dalam artikelnya yang berjudul "Nilai-nilai Budaya dalam Masalah Pemukiman" yang termuat dalam sebuah bukunya Dimensi Manusia dalam Pembangunan (Soedjatmoko, 1983), mengungkapkan bahwa dalam menghadapi masalah pemukiman yang demikian kompleks, pertanyaan yang sering timbul adalah faktor-faktor nilai budaya manakah yang perlu diperhitungkan dalam perencanaan pemukiman. Secara tentatif hanya beberapa faktor saja yang dapat dirinci. Sesungguhnya setiap pilihan yang diprioritaskan dalam usaha pembangunan mencerminkan konfigurasi dari nilai-nilai budaya yang menggerakkan suatu bangsa.

Pendekatan yang digunakan dalam penelitian ini adalah pendekatan kualitatif. Pendekatan kualitatif memiliki karakteristik sebagai berikut. Alasan penelitian, lokasi penelitian, jenis dan sumber data, teknik pengumpulan data, observasi, dan wawancara mendalam. Teknik analisis dilakukan dengan cara deskriptif kualitatif (Moleong, Lexy, 1999); (Staruss \& Juliet, 2003).

Lokasi penelitian ini adalah di Desa Ped Kecamatan Nusa Penida. Dasar pertimbangan memilih desa tersebut karena mereka yang bekerja sebagai petani rumput laut jumlahnya paling besar di. antara jumlah petani rumput laut yang ada di daerah pesisir pantai lainnya di Kecamatan Nusa Penida. Di samping itu, alasan lainnya, adalah karena di lokasi tersebut juga tampak terjadi perkembangan pembangunan yang cukup pesat terutama di bidang pembangunan fisik dan infra struktur.

Jenis data yang digunakan dalam penelitian ini adalah data kualitatif dan ditunjang oleh data kuantitatif. Data kualitatif bersumber pada informan sebagai 
data primer yaitu data hasil observasi langsung ke lapangan (field research) dan hasil wawancara mendalam. Di samping data primer juga digunakan data sekunder sebagai penunjang yakni data yang diperoleh ddri penelitian perpustakaan (library research) berupa buku-buku (literature), artikel, dan laporan hasil penelitian.

Dalam penelitian kualitatif, sesungguhnya peneliti sendiri merupakan alat pengumpulan data utama, karena si peneliti yang memahami secara mendalam tentang objek yang diteliti. Peneliti sebagai alat dapat berhubungan dengan masalah yang diteliti secara intensif (Mantra, 2004 : 27).

Selain penelitian di lapangan, data dikumpulkan dengan menggunakan pedoman wawancara dan dibantu dengan alat penelitian berupa tape recorder dan dilengkapi dengan buku catatan (note book). Alat-alat ini digunakan untuk mencatat atau merekam aspek-aspek yang menyangkut lingkungan fisik dan perilaku masyarakat yang tampak, sehingga memungkinkan tercapainya pemahaman yang lebih utuh.

Teknik yang digunakan dalam pengumpulan data adalah sebagai berikut: observasi partisipasi. Peneliti mengamati secara langsung aktivitas yang dilakukan oleh komunitas petani rumput laut. Aktivitas-aktivitas yang diamati berkaitan dengan perilaku kehidupan meliputi kehidupan keluarga, ekonomi, sosial, dan agama.

Teknik observasi ini juga digunakan dengan tujuan mengecek kebenaran data yang diperoleh tentang keadaan yang sesungguhnya di lapangan.

Wawancara Mendalam (Indepth Interview). Teknik ini digunakan untuk mengumpulkan keterangan- keterangan tentang keanekaragaman mentalitas yang dimiliki komunitas petani rumput laut dalam memandang masalah-masalah kehidupan. Teknik ini cukup mendukung dalam melengkapi data yang diperoleh dari observasi di lokasi penelitian.

Wawancara dilakukan terhadap sejumlah responden, yaitu sebanyak 50 orang yang ditetapkan sebagai sample. Keseluruhan dari jumlah tersebut, 25 orang responden orang tua (kepala keluarga) dan 25 orang responden remaja, penggolongan ini penting dilakukan untuk mendapatkan data dalam menentukan perbandingan orientasi nilai budaya antara responden orang tua dengan responden remaja, sehingga menunjukkan terjadinya dinamika orientasi nilai budaya.

Pertanyaan-pertanyaan yang diajukan terfokus kepada berbagai pandangan tentang masalah hakikat hidup, hakikat karya, hakikat waktu, hakikat hubungan sesama manusia, dan hakikat hubungan manusia terhadap alam, baik dari segi kehidupan keluarga, ekonomi, sosial, maupun kehidupan agama.

Studi Kepustakaan. Dalam penelitian ini, studi kepustakaan dilakukan dengan penelaahan kepustakaan yang relevan seperti buku-buku, artikel, hasilhasil penelitian, serta dokumen-dokumen penting lainnya. Tujuan studi kepustakaan dalam penelitian ini adalah untuk saling melengkapi dan memperkaya informasi tentang masalah yang dikaji, sehingga tingkat kebenaran informasinya menjadi lebih terjamin.

Teknik analisis data yang digunakan dalam penelitian ini adalah analisis deskriptif kualitatif dan interpretatif. Prosedur yang digunakan dalam analisis ini mencakup tahapan-tahapan klasifikasi, interpretasi, dan penarikan kesimpulan. 


\section{HASIL DAN PEMBAHASAN}

Orientasi Nilai Budaya Petani Rumput Laut Dalam Pembangunan.

Berpijak pada kerangka teori Kluckhohn tentang orientasi nilai budaya manusia dalam menjawab lima masalah dasar dalam hidup, maka orientasi nilai budaya petani rumput laut dalam pembangunan dapat dirinci sebagai berikut:

\section{Masalah Hubungan Manusia Terhadap Hakikat Hidup (MH).}

Di dalam menghadapi masalah tentang hakikat hidup, para petani rumput laut di desa Ped Kecamatan Nusa Penida memiliki konsepsi, tanggapan, persepsi yang beraneka ragam. Ada yang memandang bahwa hidup ini buruk, hidup ini baik, hidup ini dapat dirubah oleh upaya manusia agar menjadi lebih baik. Data empiris seperti yang tampak pada table 1 menunjukkan bahwa dari 50 jumlah responden sebagian besar berorientasi bahwa hidup ini pada dasarnya dapat berubah $(70 \%)$ terutama dari segi kehidupan keluarga, sedangkan $18 \%$ berpandangan bahwa hidup ini baik, dan hanya sebagian kecil (12\%) menganggap bahwa hidup ini buruk.

Konsepsi pertama itu muncul ketika budidaya rumput laut mulai diusahakan di lingkungan keluarga petani secara intensif. Sikap dan perilaku petani rumput laut yang bergelut di sektor ini cukup optimis dengan perolehan hasil yang lumayan pada setiap bulannya.

Ditinjau dari kehidupan ekonomi, lebih menonjol pada orientasi bahwa hidup ini dapat berubah sebesar $66 \%$, sedangkan $22 \%$ memandang hidup ini baik, dan $12 \%$ beranggapan bahwa hidup ini buruk. Dominannya pandangan pada perubahan hidup memang beralasan karena mata pencaharian yang ditekuni sekarang tidak pernah ada pada masa sebelumnya. Kini masyarakat pesisir telah mampu mengelola sumber daya alam laut/rumput laut yang bernilai ekonomis (innature) untuk memenuhi kebutuhan pasar ekspor.

Di bidang kehidupan sosial, juga tampak di kalangan responden sebesar $50 \%$ memiliki konsepsi bahwa hidup ini dapat berubah dan hidup ini pada dasarnya baik (40\%), hanya 10\% yang beranggapan bahwa hidup ini buruk. Sisi kehidupan sosial tercermin dalam solidaritas yang masih kuat di antara petani rumput laut baik secara ekonomis maupun non-ekonomis.

Segi kehidupan agama persentase terbesar terdapat pada orientasi bahwa hidup ini baik sebesar $60 \%$. Hal ini tercermin pada kuatnya keyakinan mereka bahwa apa yang dikerjakannya sekarang merupakan anugerah yang dilimpahkan Tuhan (Bathara yang berstana di Pura Penataran Ped) kepada umatnya di Nusa Penida.

Secara keseluruhan mengenai orientasi nilai budaya manusia dalam hubungannya dengan hakikat hidup, baik dari segi kehidupan keluarga, kehidupan ekonomi, kehidupan sosial, dan bidang kehidupan agama, proporsi variasinya dapat diungkapkan sebagai berikut. Pandangan bahwa hidup itu pada dasarnya dapat berubah sebesar $51 \%$, tertinggi pada segi kehidupan keluarga. Orientasi bahwa hidup itu baik sebanyak $35,5 \%$ terutama dari segi kehidupan agama. Hanya13,5\% yang beranggapan bahwa hidup itu buruk.

\section{Masalah Hubungan Manusia Terhadap Hakikat Karya (MK)}

Terdapat tiga variasi orientasi nilai budaya meliputi (1) Orientasi karya untuk memenuhi kebutuhan hidup, (2) Orientasi karya untuk kedudukan atau kehormatan atau gengsi, (3) Orientasi karya untuk karya (menghasilkan lebih ban- 
yak karya lagi).

Berdasarkan data yang diperoleh dari responden, menyatakan bahwa orientasi nilai budaya yang memandang karya untuk memperoleh kedudukan (status sosial di lingkungan masyarakat sekitarnya), dari segi kehidupan keluarga paling tinggi, yaitu sebesar $40 \%$. Orientasi nilai karya untuk nafkah hidup dan karya untuk karya masing-masing sebesar 30\%. Mereka berpandangan bahwa karya adalah bagian hidup. Manusia wajib bekerja, aktif, kreatif, produktif, kerja keras sehingga lebih banyak menghasilkan karya lagi.

Dalam kehidupan ekonomi, orientasi nilai budaya tentang hakikat karya untuk nafkah hidup menduduki peringkat terbesar yaitu $60 \%$ dibandingkan orientasi nilai budaya terhadap hakikat karya untuk karya hanya 10\% dan selebihnya karya untuk kedudukan sebesar 30\%. Adanya konsepsi tersebut di atas menunjukkan bahwa di kalangan petani rumput laut masih berkembang mentalitas yang memandang bahwa kerja yang mereka lakukan hanya sekedar bias mencukupi kebutuhan makan keluarga daripada untuk hal-hal lain.

Di bidang kehidupan sosial, orientasi nilai budaya untuk nafkah hidup menduduki persentase terbesar hingga $40 \%$. Karya untuk karya jumlah persentasenya akan menjadi lebih kecil, yaitu sebesar $26 \%$ dan karya untuk memperoleh kedudukan/kehormatan mencapai 34\%.

Segi kehidupan agama, terdapat orientasi nilai budaya dengan porsi terbesar pada hakikat karya untuk hidup sebesar $42 \%$. Karya untuk karya sebesar $30 \%$, dan kerja untuk kedudukan/kehormatan persentasenya hanya mencapai $28 \%$.

Apabila dilihat secara keseluruhan, orientasi nilai budaya dalam hubungan manusia terhadap hakikat karya, maka yang paling menonjol adalah karya untuk memperoleh kedudukan yaitu sebesar $43 \%$ terutama dari segi kehidupan keluarga, sedangkan karya untuk hidup sebesar 33\% terutama terbesar dalam bidang ekonomi dan karya untuk karya hanya mencapai $24 \%$ tertinggi pada bidang kehidupan keluarga dan agama.

\section{Masalah Hubungan Manusia Terhadap Hakikat Waktu (MW).}

Terdapat tiga variasi tentang hubungan manusia terhadap hakikat waktu meliputi (1) masa lampau, (2) masa sekarang, (3) masa depan. Komunitas petani rumput laut memiliki pandangan atau persepsi yang berbeda-beda dalam memandang hakikat waktu. Ada yang berorientasi ke masa lampau, masa kini, maupun masa datang.

Ditinjau dari sisi kehidupan keluarga, berkembang orientasi nilai budaya yang memandang masa sekarang menduduki porsi terbesar yaitu $50 \%$ dibandingkan berorientasi ke masa lampau yang hanya $20 \%$ dan orientasi ke masa depan sebesar $30 \%$.

Dari segi kehidupan ekonomi, proporsi terbesar adalah pada orientasi ke masa kini dan masa datang masing-masing sebesar $40 \%$ dibandingkan orientasi ke masa lampau yang hanya $20 \%$. Masa sekarang dan masa depan mendapat porsi yang sama penting dalam sebuah kehidupan. Apa yang dilakukan sekarang menentukan masa depan. Misalnya mereka kini menekuni pekerjaan di sektor rumput laut dengan penuh kesabaran dan keuletan walau hasil yang diperoleh terkadang tidak sesuai dengan harapan namun semangat untuk meraih masa depan yang lebih baik tetap ada.

Dalam bidang kehidupan sosial, orientasi nilai budaya dalam hubungan 
manusia terhadap waktu, tampak persentase terbesar pada orientasi ke masa depan yaitu sebesar $60 \%$. Di samping sebagian berorientasi ke masa datang, juga memiliki pandangan ke masa lampau dan masa sekarang. Masing-masing besarnya sama yaitu $20 \%$. Masih ada diantara komunitas petani rumput laut yang menilai pentingnya masa lampau.

Segi kehidupan agama, orientasi nilai budaya yang paling besar berada pada posisi masa sekarang yaitu sebanyak $46 \%$. Mereka percaya bahwa keselamatan maupun rintangan manusia yang bekerja di laut adalah kehendak Hyang Widhi (penguasa laut). Keyakinan ini diperkuat oleh adanya praktik kehidupan keagamaan/emosi keagamaan (Koentjaraningrat, 1987: 376-377) yang dilakukannya tampak lebih aktif daripada masa sebelum berkembangnya budidaya rumput laut.

Di samping itu, juga terdapat orientasi ke masa depan sebesar 34\%. Dapat disebutkan misalnya dalam pembuatan bangunan suci berupa padma capah yang berlokasi di pinggir pantai. Semuanya itu bermakna untuk menjaga kelangsungan mata pencaharian hidup yang ditekuni. Segi kehidupan agama yang berorientasi ke masa lampau hanya sebesar $20 \%$. Pola pikir atau mentalitas mereka masih cendrung berpatokan pada tradisi kehidupan masa lampau, misalnya dalam pelaksanaan upacara ngaben masih ada yang melakukan secara besar-besaran sehingga terkesan berpesta pora.

Secara totalitas orientasi nilai budaya tentang hakikat hubungan manusia terhadap waktu lebih cendrung pada orientasi ke masa depan yaitu sebesar $41 \%$, yang berorientasi ke masa sekarang mencapai 34\%, sedangkan $20 \%$ petani rumput laut yang masih berorientasi ke masa lampau. Di antara empat segi kehidupan, presentase yang paling tinggi adalah di bidang kehidupan sosial yang berorientasi pada masa depan, yaitu sebesar $60 \%$.

\section{Masalah Hubungan Manusia Terhadap Hakikat Alam (MA)}

Orientasi nilai budaya petani rumput laut dalam memandang hakikat hubungan manusia dengan alam meliputi tiga variasi (1) manusia tunduk terhadap alam, (2) manusia menyelaraskan diri dengan alam, (3) manusia menguasai alam.

Berdasarkan data responden menunjukkan bahwa orientasi terbesar berada pada kisaran $48 \%$ terutama dari segi kehidupan keluarga dalam hal menguasai alam.

Apabila di satu sisi ada kecenderungan menaklukan alam, tetapi di sisi lain komunitas petani rumput laut juga tunduk terhadap alam yaitu sebesar $32 \%$. Pandangan semacam ini tampak ketika kondisi air laut yang kurang bersahabat mengakibatkan rumput laut mereka rusak atau hancur. Mereka sepertinya tidak bisa berbuat banyak kecuali menerima pasrah apa yang terjadi sambil terus berusaha. Menghadapi kondisi semacam itu mereka berupaya menyelaraskan diri dengan alam lingkungan. Presentase mencapai $20 \%$.

Segi kehidupan ekonomi, presentase tertinggi juga dalam hal menguasai alam sebesar $44 \%$. Orientasi untuk senantiasa menjaga keselarasan manusia dengan alam tetap diupayakan. Perilaku ini seiring dengan konsep etika lingkungan, bagaimana manusia harus memperlakukan lingkungan, (Daldjoeni \& Ndan Suyitno, 1955); (Cheng, 2001: 179-183); (Susilo, 2003: 127). Presentase sebesar $22 \%$ dan orientasi nilai budaya yang tunduk terhadap alam yaitu sebesar $34 \%$.

Segi kehidupan sosial dalam hubungan manusia terhadap hakikat alam, 
berkembang orientasi nilai budaya yang cendrung menyelaraskan diri dengan alam yaitu sebesar $40 \%$, kuasa terhadap alam $32 \%$, sedangkan tunduk terhadap alam $28 \%$.

Dalam kehidupan agama hampir sebagian besar responden menyatakan orientasi kuasa dan tunduk terhadap alam masing-masing sebesar 40\%. Dan sedapat mungkin menyelaraskan diri dengan alam sebesar $20 \%$, misalnya melakukan upacara pakelem setiap tahun dan upacara-upacara kecil pada setiap datangnya hari-hari atau rarainan seperti kajeng kliwon, Purnama dan tilem serta hari-hari lain yang dianggap baik.

Secara keseluruhan orientasi nilai budaya petani rumput laut sebagian besar cendrung menguasai alam baik dari segi kehidupan keluarga (48\%), kehidupan ekonomi (44\%), dan kehidupan agama (40\%). Dengan demikian diperoleh presentase terbesar $41 \%$ pada orientasi nilai budaya kuasa terhadap alam, 33,5\% tunduk terhadap alam, dan orientasi selaras dengan alam sebesar $25,5 \%$.

\section{Masalah Hakikat Hubungan Manusia degan Sesama Manusia (MM)}

Ada tiga variasi orientasi nilai budaya dalam hubungan antar sesama manusia, meliputi (1) hubungan antar sesama yang sederajat (horizontal) yang lebih mementingkan kerukunan, kerja sama, (2) hubungan yang berorientasi pada atasan, senor, pejabat, orang-orang berpangkat (vertikal), (3) individualisme; menilai tingginya kemampuan sendiri atas usaha sendiri.

Orientasi nilai budaya di antara komunitas petani rumput laut di Desa Ped beraneka ragam, orientasi kepada sesama dan individu lebih menonjol terutama dari segi kehidupan keluarga masing-masing sebesar $40 \%$. Hal ini tercermin dari sikap dan perilaku mereka dalam memenuhi kebutuhan hidup keluarga. Mereka lebih berorientasi pada hidup rukun, kerja sama, tenggang rasa antar kerabat atau tetangga. Pada sisi lain mereka juga mempunyai prinsip bahwa keberhasilan akan dapat diraih atas usaha atau kemauan sendiri untuk maju. Keberhasilan selain ditentukan oleh Tuhan tetapi juga datangnya dari usaha manusia, sedangkan ketergantungan pada atasan hanya $20 \%$.

Segi kehidupan ekonomi, orientasi individu paling menonjol, yaitu sebesar $70 \%$. Dikatakan demikian karena masing-masing individu atau warga petani rumput laut memacu diri untuk memperoleh hasil yang optimal. Ini terlihat dalam hal curahan waktu kerja yang cukup tinggi, disiplin, karena waktu ditentukan oleh kondisi laut. Bagaimana manusia mengatur atau mempersiapkan dirinya secara cermat ketika tiba waktunya melaut Ketergantungan pada sesama hanya $20 \%$, sedangkan ketergantungan terhadap atasan hanya $10 \%$.

Di bidang kehidupan sosial, menduduki posisi tertinggi pada orientasi individu, yaitu sebesar $56 \%$. Orientasi ketergantungan dengan pihak atasan dalam hal ini kepada orang-orang yang berkompeten masih ada namun hanya sedikit yaitu berkisar $24 \%$. Kendati demikian, ketergantungan kepada sesama tetap ada, yaitu sebesar $20 \%$.

Dalam kehidupan keagamaan, orientasi kepada atasan lebih menonjol sebesar $42 \%$. Dalam hal ini para pemuka agama terkait dengan pelaksanaan upacara keagamaan pada masing-masing kelompok petani rumput laut. Pandangan yang berorientasi individu sebesar $36 \%$. Keyakinan terhadap usaha sendiri wajib diupayakan, sedangkan orientasi sesama hanya $22 \%$, misalnya gotong royong membuat perlengkapan upacara pakelem.

Totalitas orientasi nilai budaya petani rumput dalam hubungan manusia 
Vol. 2, No. 1, Januari 2018, 42

Available Online at https://ejournal.warmadewa.ac.id/index.php/kulturistik DOI: dx.doi.org/10.22225/kulturistik.2.1.447

dengan manusia, orientasi tertinggi ada pada posisi individu yaitu mencapai $50,5 \%$ terutama segi kehidupan ekonomi, kemudian orientasi kepada sesama sebesar 25,5\% yang tertinggi dari segi kehidupan keluarga, sedangkan $24 \%$ berorientasi pada atasan terutama segi kehidupan keagamaannya.

Tabel 1 Orientasi Nilai Budaya Responden Dalam Hubungan Lima Masalah Dasar Hidup Manusia Menurut Empat Segi Kehidupan

\begin{tabular}{|c|c|c|c|c|c|c|c|}
\hline \multirow[t]{2}{*}{ No } & \multirow{2}{*}{$\begin{array}{l}\text { Masalah } \\
\text { Dasar }\end{array}$} & \multirow{2}{*}{$\begin{array}{l}\text { Variasi } \\
\text { Orientasi }\end{array}$} & \multicolumn{4}{|c|}{ Segi Kehidupan } & \multirow{2}{*}{$\begin{array}{l}\text { Total } \\
(\%)\end{array}$} \\
\hline & & & Keluarga & Ekonomi & Sosial & Agama & \\
\hline \multirow[t]{4}{*}{ I } & \multirow[t]{4}{*}{ MH } & Buruk & 12 & 12 & 10 & 20 & 13,50 \\
\hline & & Baik & 18 & 22 & 40 & 60 & 35,00 \\
\hline & & Berubah & 70 & 66 & 50 & 20 & 51,50 \\
\hline & & Total & 100 & 100 & 100 & 100 & 100 \\
\hline \multirow[t]{4}{*}{ II } & \multirow[t]{4}{*}{ MK } & Hidup & 30 & 60 & 40 & 42 & 43,00 \\
\hline & & Kedudukan & 40 & 30 & 34 & 28 & 33,00 \\
\hline & & Karya & 30 & 10 & 26 & 30 & 24,00 \\
\hline & & Total & 100 & 100 & 100 & 100 & 100 \\
\hline \multirow[t]{4}{*}{ III } & \multirow[t]{4}{*}{ MW } & Lampau & 20 & 20 & 20 & 20 & 20,00 \\
\hline & & Sekarang & 50 & 40 & 20 & 46 & 39,00 \\
\hline & & Depan & 30 & 40 & 60 & 34 & 41,00 \\
\hline & & Total & 100 & 100 & 100 & 100 & 100 \\
\hline \multirow[t]{4}{*}{ IV } & \multirow[t]{4}{*}{ MA } & Tunduk & 32 & 34 & 28 & 40 & 33,50 \\
\hline & & Selaras & 20 & 22 & 40 & 20 & 25,50 \\
\hline & & Kuasa & 48 & 44 & 32 & 40 & 41,00 \\
\hline & & Total & 100 & 100 & 100 & 100 & 100 \\
\hline \multirow[t]{4}{*}{ V } & \multirow[t]{4}{*}{ MM } & Sesama & 40 & 20 & 20 & 22 & 25,50 \\
\hline & & Atasan & 20 & 10 & 24 & 42 & 24,00 \\
\hline & & Individu & 40 & 70 & 56 & 36 & 50,50 \\
\hline & & Total & 100 & 100 & 100 & 100 & 100 \\
\hline
\end{tabular}

Sumber: Diolah dari data primer, 2015

\section{Dinamika Orientasi Nilai Budaya petani Rumput Laut.}

Pembahasan tentang pergeseran (dinamika) orientasi nilai budaya yang terjadi pada petani rumput laut di Desa Ped Kecamatan Nusa Penida dilakukan dengan cara membandingkan konsepsi yang dianut oleh responden orang tua (kepala keluarga) dengan responden remaja. Pandangan-pandangan lebih terfokus pada masalah hubungan manusia terhadap hakikat hidup $(\mathrm{MH})$ dan hakikat karya (MK). penekanan ini didasarkan atas adanya perbedaan yang menonjol antara pandangan responden orang tua dengan remaja tentang empat segi kehidupan sebagai berikut.

Perbandingan Orientasi Nilai Budaya Kepada Keluarga dengan Remaja dalam Hubungan Manusia Terhadap Hakikat Hidup (MH).

Berdasarkan data pada tabel 2 menunjukkan bahwa hampir di seluruh segi kehidupan memperlihatkan perbedaan antara pandangan responden orang tua dengan remaja. Orientasi nilai budaya orang tua atau kepala keluarga (KK) tentang hubungan manusia terhadap hakikat hidup, memandang bahwa hidup ini adalah buruk namun manusia wajib berusaha agar hidup menjadi lebih baik. Hal ini tampak dari segi kehidupan sosial dan ekonomi tertinggi $48 \%$, agama $44 \%$, dan keluarga $40 \%$. Adanya konsepsi tersebut dimungkinkan karena para petani rumput laut terutama di kalangan orang tua memiliki keyakinan bahwa hidup ini 
Vol. 2, No. 1, Januari 2018, 43

Available Online at https://ejournal.warmadewa.ac.id/index.php/kulturistik

DOI: dx.doi.org/10.22225/kulturistik.2.1.447

dikendalikan oleh Tuhan, di samping juga usaha manusia itu sendiri.

Keadaan tersebut di atas akan berbeda bila dibandingkan dengan orientasi nilai budaya di kalangan remaja. Mereka berpandangan sebaliknya, bahwa hidup ini pada dasarnya dapat berubah oleh upaya manusia itu sendiri. pandangan ini tampak dalam semua segi kehidupan sebagai berikut. Segi kehidupan ekonomi berada pada persentase terbesar yaitu $80 \%$, selanjutnya di bidang keluarga sebesar $72 \%$, kemudian di bidang agama $60 \%$, sedangkan segi kehidupan sosial sebesar $40 \%$.

Orientasi seperti itu dapat dipahami bahwa di kalangan pemuda atau remaja jarang yang terlibat langsung di sektor pekerjaan rumput laut yang kesehariannya terendam air garam terlebih di saat aktivitas merumput harus berlangsung di terik sinar matahari. Oleh karena itu, mereka cendrung bekerja di luar sektor ini entah sebagai buruh bangunan, usaha perbengkelan baik elektronik maupun sepeda motor, sebagai sopir, dan lain-lain. Ada juga yang bekerja keluar desanya yaitu ke kota Denpasar sebagai daerah tujuan baik bekerja di sektor formal maupun nonformal.

Tabel 2 Perbandingan Orientasi Nilai Budaya Kepala Keluarga dengan Remaja dalam Hubungan Manusia Terhadap Hakikat Hidup (MH)

\begin{tabular}{|c|c|c|c|c|c|c|c|}
\hline \multirow{2}{*}{$\begin{array}{l}\text { No } \\
1\end{array}$} & \multirow{2}{*}{$\begin{array}{l}\begin{array}{l}\text { Segi Ke- } \\
\text { hidupan }\end{array} \\
\text { Keluarga }\end{array}$} & \multirow{2}{*}{$\begin{array}{c}\begin{array}{l}\text { Variasi } \\
\text { Orientasi }\end{array} \\
\text { Buruk }\end{array}$} & \multicolumn{2}{|c|}{$\begin{array}{l}\text { Kepala keluarga } \\
(\%)\end{array}$} & \multicolumn{2}{|c|}{$\begin{array}{l}\text { Remaja } \\
(\%)\end{array}$} & \multirow{2}{*}{$\begin{array}{l}\text { Total } \\
10\end{array}$} \\
\hline & & & 8 & 32 & 2 & 8 & \\
\hline & & Baik & 10 & 40 & 5 & 20 & 15 \\
\hline & & Berubah & 7 & 28 & 18 & 72 & 25 \\
\hline & & Total & 25 & 100 & 25 & 100 & 50 \\
\hline \multirow[t]{4}{*}{2} & Ekonomi & Buruk & 6 & 24 & 0 & 0 & 6 \\
\hline & & Baik & 7 & 28 & 5 & 20 & 12 \\
\hline & & Berubah & 12 & 48 & 20 & 80 & 32 \\
\hline & & Total & 25 & 100 & 25 & 100 & 50 \\
\hline \multirow[t]{4}{*}{3} & Sosial & Buruk & 6 & 24 & 5 & 20 & 11 \\
\hline & & Baik & 7 & 28 & 10 & 40 & 17 \\
\hline & & Berubah & 12 & 48 & 10 & 40 & 22 \\
\hline & & Total & 25 & 100 & 25 & 100 & 50 \\
\hline \multirow[t]{4}{*}{4} & Agama & Buruk & 11 & 44 & 5 & 20 & 16 \\
\hline & & Baik & 9 & 36 & 5 & 20 & 14 \\
\hline & & Berubah & 5 & 20 & 15 & 60 & 20 \\
\hline & & Total & 25 & 100 & 25 & 100 & 50 \\
\hline
\end{tabular}

Sumber: Diolah dari data primer, 2015

Pandangan responden orang tua dengan remaja dalam hubungan manusia terhadap hakikat karya memperlihatkan perbedaan. Secara rinci dapat dilihat pada tabel berikut. 
Vol. 2, No. 1, Januari 2018, 44

Available Online at https://ejournal.warmadewa.ac.id/index.php/kulturistik DOI: dx.doi.org/10.22225/kulturistik.2.1.447

Tabel 3 Perbandingan Orientasi Nilai Budaya Kepala Keluarga dengan Remaja dalam Hubungan Manusia Terhadap Hakikat Karya (MK)

\begin{tabular}{|c|c|c|c|c|c|c|c|}
\hline \multirow{2}{*}{$\begin{array}{l}\mathbf{N o} \\
1\end{array}$} & \multirow{2}{*}{$\begin{array}{l}\text { Segi Kehidupan } \\
\text { Keluarga }\end{array}$} & \multirow{2}{*}{$\begin{array}{l}\text { Variasi Orientasi } \\
\text { Hidup }\end{array}$} & \multicolumn{2}{|c|}{$\begin{array}{l}\text { Kepala keluarga } \\
(\%)\end{array}$} & \multicolumn{2}{|c|}{$\begin{array}{l}\text { Remaja } \\
(\%)\end{array}$} & \multirow{2}{*}{$\begin{array}{l}\text { Total } \\
12\end{array}$} \\
\hline & & & 8 & 32 & 4 & 16 & \\
\hline & & Kedudukan & 10 & 40 & 6 & 24 & 16 \\
\hline & & Karya & 7 & 28 & 15 & 60 & 22 \\
\hline & & Total & 25 & 100 & 25 & 100 & 50 \\
\hline \multirow[t]{4}{*}{2} & Ekonomi & Hidup & 15 & 60 & 6 & 24 & 21 \\
\hline & & Kedudukan & 7 & 28 & 9 & 36 & 16 \\
\hline & & Karya & 3 & 12 & 10 & 40 & 13 \\
\hline & & Total & 25 & 100 & 25 & 100 & 50 \\
\hline \multirow[t]{4}{*}{3} & Sosial & Hidup & 11 & 44 & 7 & 28 & 18 \\
\hline & & Kedudukan & 8 & 32 & 7 & 28 & 15 \\
\hline & & Karya & 6 & 24 & 11 & 44 & 17 \\
\hline & & Total & 25 & 100 & 25 & 100 & 50 \\
\hline \multirow[t]{4}{*}{4} & Agama & Hidup & 10 & 44 & 9 & 36 & 19 \\
\hline & & Kedudukan & 9 & 36 & 8 & 32 & 17 \\
\hline & & Karya & 6 & 20 & 8 & 32 & 14 \\
\hline & & Total & 25 & 100 & 25 & 100 & 50 \\
\hline
\end{tabular}

Sumber: Diolah dari data primer, 2015

Tabel 3 di atas menunjukkan bahwa orientasi nilai budaya kepala keluarga petani rumput laut berpandangan bahwa karya untuk hidup dan juga kedudukan. Persentase terbesar terdapat pada orientasi karya untuk hidup, yaitu sebesar $60 \%$ terutama pada segi kehidupan ekonomi, selanjutnya bidang sosial dan agama masing-masing $44 \%$ kemudian kehidupan keluarga $40 \%$.

Pandangan tersebut memang beralasan. Sebagai masyarakat agraris yang hidup di pedesaan, pandangan mereka terhadap karya sangat sederhana. yang paling penting didahulukan adalah bagaimana bekerja agar dapat mendatangkan nafkah, terutama dalam memenuhi kebutuhan dasar keluarga. Apabila kebutuhan tersebut telah mencukupi barulah mengarah kepada hal-hal lain, misalnya yang menyangkut prestise atau kedudukan seperti menyekolahkan anak-anaknya sampai jenjang perguruan tinggi, pemilikan kendaraan, merenovasi rumah tinggal, adakalanya menabung. Orientasi demikian dapat dilihat dalam empat segi kehidupan. peringkat terbesar terdapat pada bidang kehidupan keluarga sebesar $60 \%$, kehidupan sosial $44 \%$, ekonomi $40 \%$ dan agama $36 \%$.

Jika dibandingkan dengan orientasi nilai budaya di kalangan remaja, tampak bahwa pandangan remaja lebih mengarah kepada karya untuk karya. proporsi terbesar terdapat pada kehidupan MK 1 (60\%), MK 3 (44\%), MK 2 (40\%), dan MK 4 (32\%). Tanggapan tersebut menyiratkan bahwa di kalangan remaja memiliki kemauan keras untuk maju dan kehidupan yang lebih baik dari kondisi hidup orang tua mereka. Hal ini tentu didukung oleh tingkat pendidikan dan pengalaman yang diperoleh lebih tinggi dari orang tuanya, dengan latar belakang tersebut, mereka lebih cendrung menekuni pekerjaan diluar sektor rumput laut dan sebaliknya para orang tualah yang mayoritas sebagai petani rumput laut.

\section{SIMPULAN}

Berdasarkan hasil temuan tersebut di atas, disimpulkan bahwa, orientasi nilai budaya komunitas petani rumput laut di desa Ped kecamatan Nusa Penida dalam memandang hakikat hidup, hakikat karya, hakikat waktu, hakikat hub- 
Vol. 2, No. 1, Januari 2018, 45

Available Online at https://ejournal.warmadewa.ac.id/index.php/kulturistik DOI: dx.doi.org/10.22225/kulturistik.2.1.447

ungan manusia dengan alam, dan hakikat hubungan antar sesama manusia, tampak bervariasi. Terjadi pergeseran (dinamisasi) orientasi petani rumpu laut yang dianut kalangan orang tua dan remaja yang cendrung bekerja di luar sektor rumput laut. Adanya perbedaan konsepsi bahwa hidup ini harus berubah kearah yang lebih baik atas dasar usaha manusia itu sendiri dengan kerja keras menghadapi tantangan alam laut. Sebaliknya kalangan remaja berorientasi bekerja keluar dari desanya menambah pengalaman mencari penghidupan yang lebih baik daripada orang tuanya untuk kepentingan masa kini dan yang lebih penting orientasi ke masa depan.

\section{DAFTAR PUSTAKA}

Cheng, C.-Y. (2001). Tentang etika lingkungan dari Tau dan Ch' I, " May Larry. Ed. 2001. Etia terapan I: Sebuah pendekatan multikultural. Yogyakarta: Tiara Wacana.

Daldjoeni, \& Ndan Suyitno, A. (1955). Pedesaan lingkungan dan pembangunan. Bandung: Alumni.

Inkeles, A. (1994). Modernisasi manusia", dalam Weiner, Myron, Modernisasi dinamika pertumbuhan. Yogyakarta: Gadjah Mada University Press.

Koentjaraningrat. (1987). Kebudayaan mentalitas dan pembangunan. Jakarta: Gramedia.

Mantra, I. B. (2004). Filsafat penelitian dan metode penelitian sosial. Yogyakarta: Pustaka Pelajar.

Mattulada. (1985). Mentalitas dan ciri-ciri kepribadian bangsa Indonesia dalam Bachtiar, Harsya W. Dkk. Yogyakarta: Hanindita.

McClelland, D. C. (n.d.). Dorongan hati menuju modernisasi", dalam Weiner, Myron. Modernisasi dinamika pertumbuhan. Yogyakarta: Gadjah Mada University Press.

Moleong, Lexy, J. (1999). Metodologi penelitian kualitatif. Bandung: Remaja Rosdakarya.

Soedjatmoko. (1983). Nilai-nilai Budaya dalam Pemikiman", dalam Dimensi manusia dalam pembangunan. Jakarta: LP3ES.

Staruss, A., \& Juliet, C. (2003). Dasar-dasar penelitian kualitatif, Terj. Yogyakarta: Pustaka Pelajar.

Susilo, Y. E. B. (2003). Menuju keselarasan lingkungan. Surabaya: Averroes. 